\title{
Tissue erosion with perianal warts in HIV infection
}

\author{
Mayura Nathan, Steve Beck
}

\begin{abstract}
A case of painful tissue erosion due to perianal warts is described with HIV infection. Such a development can be avoided by frequent and careful monitoring.
\end{abstract}

(Genitourin Med 1993;69:312-313)

\section{Case history}

A 25 year old male referred himself with persistent gnawing perianal pain associated with his perianal warts, of two weeks duration. The pain gradually worsened and was intense at presentation. A year previously his perianal warts were surgically removed in his residential district but recurred 2 weeks later. Over two years earlier he had been found to be Hepatitis B antigen and HIV antibody positive.

On examination there were multiple large warts, some measuring $5 \mathrm{~cm}$. Two warts measuring $3 \mathrm{~cm}$ were found to be eroding into the perianal tissues. These warts were clearly circumscribed but were buried into the apposing perineal tissues. There was fresh blood oozing from the eroded area. His "gnawing" pain was located to the eroded tissue of the perineum. His CD4 count was $0.54 \times 10^{9} / 1(27 \%)$. Laser excision of the larger warts with ablation of the smaller warts $(<1 \mathrm{~cm})$ were carried out under local anaesthesia with immediate relief of pain. Extension of the exophytic warts into the anal canal (4 cm spread) was noted and the treatment extended to the anal mucosa. Biopsy specimens were obtained from the eroding warts, adjoining anal mucosa and the skin

Department of Genitourinary Medicine, Doncaster Royal Infirmary, Doncaster

Mayura Nathan

Department of

Histopathology,

Doncaster Royal

Infirmary, Doncaster Steve Beck

Address correspondence to: Dr P M Nathan, Dept. of GU Medicine, Doncaster Royal Infirmary, Armthorpe Royal, Doncaster, S. Yorks DN2 5LT, UK.

Accepted for publication 28 April 1993

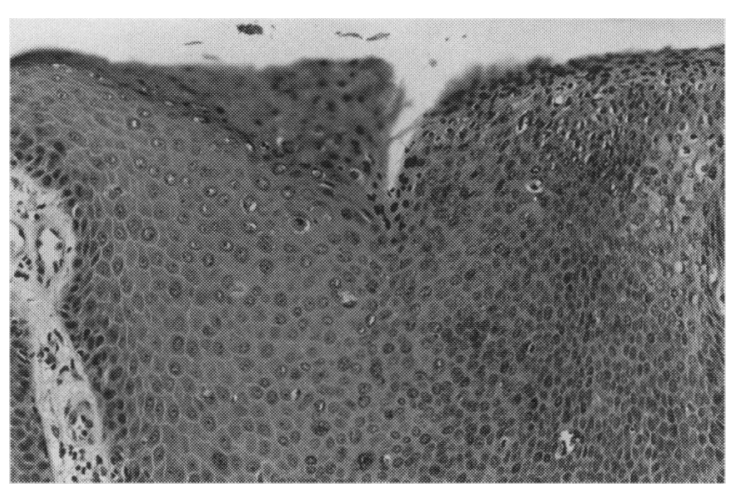

Histological appearances of anal intraepithelial neoplasia grade 2-3 and adjacent wart virus changes. ( $H$ and $E, \times 150)$. overlying the eroded tissues. Histologe demonstrated typical features of condyloma tous wart virus infection with an overall exophytic growth pattern. There was no evidence of invasion of the underlying stroma by the proliferating squamous epithelium. There were extensive changes of high grade (gradè 2-3) anal intraepithelial neoplasia but no evio dence of invasive carcinoma (fig).

HPV typing was performed using in sitis hybridisation and HPV types 6 and 11 were detected. Subsequent follow-up showed excellent healing with minimal scarring and the patient remained free of pain. $\mathrm{He}$ deveF oped further small exophytic warts $(<1 \mathrm{~cm})$ both at the anal mucosal site and at the perio anal skin. The treatment was extended wit systemic interferon injections in addition to laser ablation of new exophytic warts.

\section{Discussion}

Most anogenital warts are mucocutaneous outgrowths precipitated by HPV infection The mechanisms by which the HPV stimu lates the formation of such appendages arg not fully understood. ${ }^{1}$ On occasion the muco cutaneous proliferation is directed down wards into the deeper tissues leading to invasion of the underlying organs, the socalled Buschke-Lowenstein tumour Although it is suspected that some form of immune deficiency ${ }^{34}$ may play a part, the trigger factors for downward growth is not known. Recent observations indicate the pos? sibility of altered virulence as one of the. mechanisms concerned. ${ }^{5}$ The latter was seet in association with HPV Type 6.

We describe here a case of perianal warts with localised pain in which there was nछ invasion of the underlying tissueso Histological examination of the pedicle of the warts did not demonstrate any proliferation into the underlying tissues, yet clinical examin nation demonstrated penetration into the deeper tissues that were pressing on some of the warts. There were no carcinomatous changes seen either in the offending warts of the tissues eroded by them. Howeverg intraepithelial neoplasia changes have been noted in the anal mucosa. Such changes ar well documented in HIV infection. ${ }^{6}$ This patient's CD4 counts indicate mild to moderate immune suppression and he was asymptomatic otherwise. There has been some evidence of increased presence of HPV DNA in the anal mucosal cells with increasing 
immune deficiency, ${ }^{7}$ in addition to anal dysplasia by cytological evidence, under such circumstances. ${ }^{8}$ A possible explanation in this patient for tissue invasion may well be the rapidity of the growth of the warts and the pressure on the surrounding tissues. Rapid growth of anogenital warts in HIV infected individuals is well recognised. ${ }^{9}$ Such considerations will emphasise the need for early intervention. ${ }^{2}$ In addition, close monitoring may be necessary in homosexual men with HIV infection and perianal warts, as intraepithelial neoplasia and squamous carcinoma may occur under such conditions. ${ }^{10} \mathrm{~A}$ number of previous reports have suggested that such changes are closely related to HPV 16 infection. ${ }^{11}$ In one study, of HIV infected individuals the most common presenting symptoms and signs for squamous cell carcinoma of the anus were anal mass, pain and bleeding. ${ }^{12}$ In addition, the increased risk of intraepithelial neoplasia in the presence of infection with multiple HPV types ${ }^{6}$ will call for increased vigilance in such patients.

It is suggested that close and frequent monitoring of patients with perianal warts and HIV infection will be helpful in avoiding patient discomfort and tissue invasion.

The authors thank Dr Michael Wells, Dept. of Pathology, The authors thank Dr Michael Wells, Dept. of Path
University of Leeds for his help with the HPV typing.
1 Syrjanen KJ. Virology and pathogenesis. Genital papilloma virus infections and their sequelae: Proceedings of the International symposium; 17th World congress of Dermatology Berlin, May 1987:pp 5-15.

2 Tessler AN, Applebaum SM. The Buschke-Lowenstein tumor. Urology 1982;20:36-9.

3 Carson LF, Twiggs LB, Fakushima M, Ostrow RS, Faras AJ, Okagaki T. Human genital papilloma infections: an valuation of immunologic competence in the genita neoplasia-papilloma syndrome. Am $\mathcal{f}$ Obstet Gynecol 1986;155:784-9.

4 Cauda R, Tyring SK, Grossi CE, et al. Patients with condyloma acuminata exhibit decreased interleukin 2 and interferon gamma production and depressed natural killer activity. F Clin Immunol 1987;7:304-11.

5 Boshart $M$, zur Hausen $\mathrm{H}$. Human papilloma viruses in Buschke-Lowenstein tumours: physical state of the DNA and identification of a tandem duplication in the noncoding region of a Human papilloma virus 6 subtype. F Virol 1986;58:963-6.

6 Palefsky JM, Gonzales J, Greenblatt RM, Ahn DK Hollander $H$. Anal intraepithelial neoplasia and anal papilloma virus infection among homosexual males with group IV HIV disease. $\mathscr{f} A M A$ 1990;263:2911-6.

7 Melbye M, Palefsky J, Gonzales J, et al. Immune status as a determinant of Human papilloma virus detection and its association with anal epithelial abnormalities. Int $\mathcal{f}$ Cancer 1990;46:203-6.

8 Frazer IH, Medley G, Crapper RM, Brown TC, Mackay IR. Association between anorectal dysplasia, human papillomavirus and human immunodeficiency virus papillomavirus and human immunodeficiency virus

9 Buchmann P, Christen D, Rudlinger R, Geroulanos S. Anal condylomata acuminata: a prospective comparison of HIV positive and negative patients. Chirurg 1991;62: $32-5$.

10 Rudlinger R, Buchmann P. HPV16-positive bowenoid papulosis and squamous cell carcinoma of the anus in an HIV positive man. Dis Colon Rectum 1989;32: 1043-5.

11 Bradshaw BR, Nuovo GJ, DiCostanzo D, Cohen SR Human papilloma virus Type 16 in a homosexual man. Arch Dermatol 1992;128:949-52.

12 Lorenz HP, Wilson W, Leigh B, Crombleholme T, Schecter W. Squamous cell carcinoma of the anus and HIV infection. Dis Colon Rectum 1991;34:336-8. 